\title{
Oil and the Niger Delta People: The Injustice of the Land Use Act
}

\author{
By Kaniye S.A. Ebeku, Port Harcourt, Nigeria / Canterbury, UK *
}

\begin{abstract}
"All lands and natural resources (including mineral resources) within the Ijaw territory belong to the Ijaw communities and are the basis of our survival...We cease to recognise all undemocratic decrees that rob our peoples/communities of the right to ownership and control of our lives and resources, which were enacted without our participation and consent. These include the Land Use Decree and the Petroleum Decree..."
\end{abstract}

(Kaiama Declaration, 11 December 1998)

\section{Introduction}

Oil exploitation in the Niger Delta region of Nigeria began in 1956, after a long search for oil which began in 1906. By 1956 production has reached 5,100 barrels per day (p/d) and the first export to Europe was made that year. At independence in 1960 Nigeria had become self sufficient in crude oil, producing 20,000 barrels $\mathrm{p} / \mathrm{d} .{ }^{1}$ In 1961 production was $46,000 \mathrm{p} / \mathrm{d}$; and with the construction of trans-Niger pipeline in 1965 and the exploitation of off-shore fields, production leaped to $275,000 \mathrm{p} / \mathrm{d}$, and to 420,000 prior to the Nigerian civil war which started in 1967. Although the civil war lasted up to 1970, it does not seem that the difficulties of the war time significantly affected oil production as the million barrel daily mark was passed in 1970 and by 1973 had doubled to 2.06 million p/d. ${ }^{2}$

* I acknowledge the contributions of my supervisors, Wade Mansell and Prof. S.R. Harrop at Kent Law School, University of Kent at Canterbury, UK, who read through the earlier draft of this article and made useful comments. However, all errors in this article are solely mine. Pearson, Petroleum and the Nigerian Economy, Stanford University Press, Stanford, California, 1970, quoted in Watts, Silent violence: Food, Famine \& Peasantry in Northern Nigeria, University

2 of California Press, Berkeley, California, 1983, p. 471.

Watts, supra n. 1, at 473. 
Before the discovery and exploitation of oil, Nigeria had an agrarian economy. ${ }^{3}$ But as the above figures indicate, since its discovery and exploitation oil has been rapidly growing in importance in the Nigerian economy. Available evidence shows that by 1972 oil constituted $83 \%$ of Nigerian exports. With regards to revenue, the share of oil in federal government revenue rose from $17 \%$ in 1971 to $71 \%$ in 1973 , and to $86 \%$ in 1975 . $^{4}$ Sources also indicate that this trend has remained ever since. So that by early 1990 s, oil revenue accounted for over $90 \%$ of Nigeria's foreign exchange receipts. Oil revenue within this period also provided for $70 \%$ of budgetary revenues and $25 \%$ GDP. ${ }^{5}$ In 1998 , the minister of finance indicated that the federal government income from sales of its 'equity in crude oil $^{16}$ was US\$7,706 million and from royalty and Petroleum Profits Tax, ${ }^{7}$ US\$ 4,288 million; "together they made up $88 \%$ of the government's foreign exchange earnings for the year 1997". 8 Presently oil is still the mainstay of the Nigerian economy. In its yearly Report and Statement of Account recently published for the year 2000, the Central Bank of Nigeria stated that "oil accounted for N1.59 trillion or $83.5 \%$ of the total gross revenue" for the year. $^{9}$

As is the case with other oil-producing countries, the exploitation of oil in Nigeria is carried out under some legislation. ${ }^{10}$ The most important oil-related legislation in Nigeria

For a comparative information on the contributions of agriculture and crude oil to the Nigerian economy, see Iwaloye / Ibeanu, The peoples of Nigeria, in: Okafor (ed.), New Strategies For Curbing Ethnic \& Religious Conflicts in Nigeria, Enugu: Fourth Dimension Publishing Co., Ltd, 1997, pp. 62-64.

Watts, supra n.1, at p. 473.

5 Khan, Nigeria: The Political Economy of Oil, Oxford University Press, Oxford, 1994, p. 183; Frynas, Is political Instability Harmful to Business? The case of Shell in Nigeria, University of Leipzig Papers on Africa (Politics and Economics, No.14), 1998.

6

Through the Nigerian National Petroleum Company (NNPC) the federal government "currently holds about $57 \%$ participating interest in the various joint ventures it has with the major oil companies in Nigeria". See generally, Olisa, Nigerian Petroleum Law and Practice, $2^{\text {nd }}$ ed., Jonia Ventures Ltd., Lagos, 1997, pp. 67-71.

1958 (Cap 354, Laws of the Federation of Nigeria 1990 Edition).

1998 Budget Briefing by the Minister of Finance, 7.

9 See "Nigeria earns N 1.59 trillion from Oil" (The Guardian, 5 July 2001, 1). This can be regarded as an official confirmation of the findings of an inter-governmental body based in Sweden, which had reported that "oil resources of the Niger Delta still provides over 80 percent of government revenue". International IDEA, Democracy in Nigeria: Continuing Dialogue(s) For Nation-Building, series No. 10, Stockholm, 2000, p. 142.

10 Virtually all the oil-related legislation, including the Land Use Act and the Petroleum Act, were made by successive military governments in Nigeria (since independence in 1960 Nigeria has been ruled most of the time by military dictators). The Military Decrees (as the legislation were called) were later re-designated as Acts in 1980 by virtue of the Adaptation of Laws (Re-designation of Decrees, Etc.) Order 1980. In this article, the words 'Decree' and 'Act' shall be used interchangeably. 
include: the Petroleum Act $1969,{ }^{11}$ Oil pipelines Act $1956,{ }^{12}$ Oil in Navigable Waters Act $1968,{ }^{13}$ Federal Environmental Protection Agency Act 1988, ${ }^{14}$ and the Land Use Act 1978. ${ }^{15}$ By the Petroleum Act (continuing a colonial policy) the entire property in petroleum (mineral oils) is vested in the state. ${ }^{16}$ The result is that the federal government has absolute right and control over oil resources in the country, which is found only in the Niger Delta region of the country. It farms out oil mining rights to oil companies and receives rents and royalties from them. ${ }^{17}$ As has been seen above, oil has realised so much money for the Nigerian state over the years.

One unique aspect of Nigerian law can be found in its law of property. Under the laws of most common law countries 'land' includes mineral oils entrapped in the land. ${ }^{18}$ But this is not the case with Nigeria. Section 16 of the Interpretation Act $1964^{19}$ explicitly excludes mineral oils from the meaning of land. And while oil is vested in the state ownership of land supporting oil remained vested in communities and families until 1978 when the Land Use Act (hereafter LUA) was made. The Act (promulgated as a Decree by a military government) vests all the lands comprised in the territory of a state of the federation in the governor of the state in 'trust ${ }^{20}$ for all Nigerians. It is significant to note that before the

11

12

13

14

15

16

17

18

19

20

Cap 350, Laws of the Federation of Nigeria 1990 Edition.

Cap 338, Laws of the Federation of Nigeria 1990 Edition.

Cap 337, Laws of the Federation of Nigeria 1990 Edition.

Cap 131, Laws of the Federation of Nigeria 1990 Edition.

Cap 202, Laws of the Federation of Nigeria 1990 Edition.

Section 1.

Ajomo, Ownership of Oil and the Land Use Act (1982), Nigerian Current Law Review 330.

See, for example, Section 206(1) of the English Law of Property Act, 1925.

Cap 192 of the Laws of the Federation of Nigeria 1990 Edition.

The word 'trust' is used here in a loose sense; the governor is not a trustee in the strict English sense. In the words of a learned author, "considering the provisions of the Act as a whole, it would appear that the word 'trust' is used under section 1 in a loose sense... It is obvious that the governor is under no duty or obligation to give account to the beneficiaries in the management of the trust property as is the case under English law. Nigerians who are even sui juris cannot put an end to the land vested in the state. Similarly, they do not have the right to appoint any other person, as in the case of trusteeship... [Whatever] may be [the governor's] shortcomings in the administration of the land, the beneficiaries cannot sue for redress." Tobi, Handbook on the Land Use Act, Ahmadu Bello University Press, Zaria, 1989, pp. 47-8. However it is difficult to understand what the author means by the statement: "The governor of a state cannot be designated as a trustee neither in the strict English sense nor in the loose customary sense of the word" (Ibid., at 47). The author did not say in what 'special' loose sense, then, a governor is designated as a trustee. It is submitted, with respect, that the governor under the Land Use Act 1978 is a trustee in the loose customary sense of it as stated in Amodu Tijani v. Secretary, Southern Nigeria (1923), 4 N.L.R. 18, and a host of other cases. See generally Adigun, The Genesis of the concept of trust in Nigerian law, in: Omotola (ed.), Essays in Honour of Judge T.O. Elias, University of Lagos Press, 
promulgation of the Act oil companies that had obtained mining rights from the federal government approached oil-bearing/land-owning communities for a right of access to the land for its operations. This was a way by which the communities had some sense of participation in oil operations, as they received some compensation for granting access and for any damage to land and any surface rights thereon. It would appear that this sense of participation has been lost since the unity of land rights with oil rights in 1978. Most scholarly works on oil exploitation activities in the Niger Delta have concentrated on the environmental impact of oil exploitation and the under-development of the region despite the huge revenue oil exploitation has yielded to the Nigerian state. ${ }^{21}$ There has not been any systematic scholarly analysis of the impact of the LUA on the Niger Delta people. ${ }^{22}$ This is the lacunae which this paper attempts to fill. It will be shown that the impact of the LUA on the Niger Delta people raises questions of injustice which themselves could exacerbate an unstable position in the region. But before embarking on the examination of the relevant sections of the Act and its impact on the Niger Delta people, it is useful to briefly consider the issues of ownership of oil and ownership of land supporting oil before the enactment of the LUA. This is the first task we shall undertake here and it will serve as our framework for analysis. From this we shall move to the impact of the LUA on the Niger Delta people. The paper will end with some concluding remarks.

\section{Background and Context}

\subsection{Ownership of oil in Nigeria}

Lagos, 1987, pp. 74-94; Jegede, The Position of Head of Family: Is he a trustee in the strict English sense?, (1966) Nigerian Bar Journal 164.

21 See, for example Naanen, Oil-producing Minorities and the Restructuring of Nigerian Federalism: The case of the Ogoni People, (1995) Journal of Commonwealth \& Comparative Politics, 46; Okonmah, Right to a Clean Environment: The case for the People of Oil-Producing Communities in the Nigerian Delta, (1997) Journal of African Law, 43; Hutchful, Oil Companies and Environmental Pollution in Nigeria, in: Ake, Political Economy of Nigeria, Longman Publishers, New York, 1985, p. 113.

22

Compare Etikerentse, The impact of the 1978 Land Use Act on Land Acquisition Compensation by Oil Companies, [1984/85] OGLTR 72; Kassim-Momodu, Impact of the Land Use Act on Petroleum Operations in Nigeria, [1990] 4 JERL 291; Omotola, Interpreting the Land Use Act, [1992] 1 Journal of Nigerian Law 108. 
The search for and exploitation of oil in Nigeria started in the colonial era. ${ }^{23}$ The British colonial authorities regulated these activities through a number of laws. The major oilrelated colonial statute was the 1914 Mineral Oils Ordinance ${ }^{24}$ which was promulgated to "regulate the right to search for, win and work mineral oils". This law did not make any provision for the ownership of oil. The ownership of oil was later provided for in the Minerals Ordinance 1916; and also in the 1945 Minerals Act which replaced it. Section 3 of this Act (the Act came into force on 25 February 1946) specifically vested mineral oils in the crown, thus:

"The entire property in and control of all mineral oils in, under or upon any lands in Nigeria, or of all rivers, streams and water courses throughout Nigeria is and shall be vested in the crown [state], save in so far as such rights may in any case have been limited by any express grant made before the commencement of this Act.",25

Some important amendments of the 1914 Ordinance were made in 1925, 1950, and 1959. Under section 2 of the 1925 amendment "mineral oil" was defined as including "bitumen, asphalt and all other bituminous substances" with the exception of coal (which was covered by the 1945 Minerals Act). The 1950 amendment added a new section ${ }^{26}$ whereby the submarine areas of Nigeria's territorial waters were brought under the ambit of the Ordinance. The 1959 amendment extended the legislative competence of Nigeria's federal legislature (under the 1959 colonial constitution Nigeria was a federation with a centre and three Regions) to cover the submarine areas of other waters on which the federal legislature may make legislation in future, in matters relating to mines and minerals. This later amendment might have been made in exercise of the right recognised under Art.2 of the Geneva Convention on the Continental Shelf. ${ }^{27}$

For historical accounts of the Nigerian oil industry, see Ajomo, Oil in Nigeria, in: Elias (ed.), Law and Social Change in Nigeria, Lagos: Evans Brothers, 1972, Chapter 8; Ajomo, Law and Changing Policy in Nigeria's Oil Industry, in: Omotola / Adeogun (eds.), Law and Development, Lagos University Press, Lagos, 1987, p. 84; Etikerentse, Nigerian Petroleum Law, Macmillan Publishers, London, 1985, Chapter 1; Kassim-Momodu, Gas Re-injection and the Nigerian Oil industry, (1986/87) Journal of Private and Property Law, 69; Omoregbe, The Legal Framework for the Production of Petroleum in Nigeria, (1987) Journal of Energy and Natural Resources Law, 273; Schatzal, Petroleum in Nigeria, Ibadan: Oxford University Press, 1969, esp. pp.1-4. No. 17 of 1914.

25 This provision is similar to section 1(1) of the Petroleum (Production) Act, 1934 of Great Britain. Section 10 .

This article did not create a new right, rather it recognises and effectively codifies existing customary international law. In North Sea Continental Shelf cases, 1969 ICJ Reports, 3, the International Court of Justice made this point clear when commenting on the nature of state rights over continental shelf resources. The court said it - "...entertains no doubt that the most fundamental of all the rules relating to the continental shelf is that enshrined in Article 2 of the 1958 Geneva Convention, though quite independent of it - namely that the rights of the coastal state in respect of the area of continental shelf that constitutes a natural prolongation of its land territory into and 
The result of all these laws was to vest in the Crown/State the absolute right and control over the colonial state's oil resources, both onshore and offshore. Given the revenue potentials of oil it is hardly surprising that Nigerian nationalists resented these laws. ${ }^{28}$ In fact, one of Nigeria's leading nationalist described these laws as "obnoxious". 29 The implication of this, of course, was that it was unjust because it deprived the colonised peoples of the benefit of their "natural property". It is therefore paradoxical that the same persons who had so resented colonial statutes on mineral oils moved to retain the essence of these laws after independence. This was done by a constitutional provision drafted by themselves in 1963 (three years after independence). Section 158(1) of this constitution provided:

"....all property which, immediately before the date of the commencement of this constitution, was held by the crown or by some other body or person (not being an authority of trust for the crown) shall on that date, by virtue of this subsection and without further assurance, vest in the president and be held by him on behalf of or, as the case may be, on the like trust for the benefit of the government of the federation; and all property which immediately before the date aforesaid, was held by an authority of the federation on behalf of or in trust for the crown shall be held by that authority on behalf of, or as the case may be, on the like trusts for the benefit of the government of the federation..."

There is a belief in some quarters that the Nigerian nationalist (Nnamdi Azikiwe ${ }^{30}$ ) who had denounced colonial statutes on mineral oils made a volte-face on such legislation after independence because he found himself as the 'inheritor' of the property secured by the statutes. ${ }^{31}$ Critics have also suggested that the Nigerian civil war of 1967-70 was a cynical

under the sea exist ipso facto and ab initio, by virtue of its sovereignty over the land, and as an extension of it in exercise of sovereign rights for the purpose of exploring the seabed and exploiting its natural resources. In short, there is here an inherent right. In order to exercise it, no special legal process has to be gone through, nor have any special acts to be performed. Its existence can be declared (and many states have done this) but does not need to be constituted. Furthermore, the right does not depend on its being exercised. To echo the language of the Geneva Convention, it is 'exclusive' in the sense that if the coastal state does not choose to explore or exploit the areas of shelf appertaining to it, that is its own affair, but no one else may do so without its express consent..." The 1982 Geneva Convention on the Law of the Sea retains the operative wording of Art. 2 of the 1958 convention on the Continental Shelf.

See Coleman, Nigeria: Background to Nationalism, University of California Press, Berkeley, 1958, p. 228. In contrast with Nigeria, in the case of the Ghanaian diamond industry landowners were paid royalties, which were a proportion of the net profits accruing from the mining concessions. See Greenhalgh, West African Diamonds, 1919-1983: An Economic History, Manchester University Press, Manchester, 1985, pp. 86-113.

See http://nigeriaworld.com/feature/publication/omoruyi/oil.html, 23 Mar 2001.

Nigeria's first indigenous ceremonial president (Head of State).

See footnote 29 above. 
war for the control of oil resources in the Niger Delta ${ }^{32}$ (located in the Eastern Region of Nigeria); the war was caused by the attempt of the Eastern Region to secede from Nigeria. Before the war there had been a military coup in 1966 which had ousted elected officers from office; a military/dictatorial government had been established and the 1963 constitution had been suspended. In 1969, in the course of the war, the Federal Military Government (as the usurper regime was styled) promulgated a decree called the Petroleum Decree, by which it re-asserted state ownership of oil resources. Section 1 of this Decree provides as follows:

“(1) The entire ownership and control of all petroleum ${ }^{33}$ in, under or upon any lands to which this section applies shall be vested in the state.

(2) This section applies to all lands (including land covered by water) which-

is in Nigeria; or

is under the territorial waters of Nigeria; or forms part of the continental shelf."

The petroleum Decree was followed in 1978 by the Exclusive Economic Zone Decree ${ }^{34}$. This Decree vests in the federal Republic of Nigeria sovereign and exclusive rights with respect to the exploitation of natural resources (including oil) of the seabed, the subsoil and superjacent waters of the Exclusive Economic Zone (EEZ). The combined effect of this Decree and the Petroleum Decree is enormous. As one scholar has argued, "the provisions

One critic argues that "the control of the oil resources was of obvious strategic importance to both conflicting parties [Nigeria and Biafra]. At the beginning of the war, the Biafran government insisted that Shell pay the royalties due July 1967 since they controlled the oil fields and Bonny oil terminal at that time. They were confident that the revenues from oil would enable them to purchase the needed arms for the war. Likewise, one of the purposes of the creation of 12 states in 1967 by Gowon was to isolate the heart of Igboland from the oil-rich areas and the Bonny terminal." Robinson, Ogoni - The Struggle continues, $2^{\text {nd }}$ ed. 1996, 28 - A Publication of the World Council of Churches, Geneva, Switzerland. Making a similar argument, another critic has said: "The capture of Bonny by the federal troops was fortunate in more ways than one, for Bonny was a real prize. Not only did it control the sea passage from the Atlantic ocean into Port Harcourt, socalled Biafra's main port, it was also the main oil terminal for Nigeria's main oil company, ShellBP. It was the port of export for most of Nigeria's oil. Its capture also came at an opportune moment: at a time when there was a tussle over oil royalty payments. If Ojukwu got paid the royalties for the half year ended June, 1967 his exchequer would not only have swollen, he would also have had considerable foreign exchange at his disposal to enable him to pursue his war aims with greater vigour. One retains a niggling suspicion that Lagos might have been informed that if she did have some presence in the oil areas of Eastern Nigeria, there might be justification for paying the royalties, whereas if Ojukwu continued to control the entire oil region, he would have a right to the royalties, since possession is nine parts of the law." Saro-Wiwa, On a Darkling Plain, Saros International Publishers, Port Harcourt, 1989, p. 98.

'Petroleum' means “mineral oil (or any related hydrocarbon) or natural gas as it exists in its natural state in strata, and does not include coal or bituminous shales or other stratified deposits from which oil can be extracted by distillation." (Section 15). Cf. the definition of petroleum under the Zambian Petroleum Act, Cap 435 of the Laws of Zambia 1995 Edition.

No.28 of 1978 (Cap 116, Laws of the Federation of Nigeria 1990 Edition). 
of the Petroleum Act [the Decrees were later re-designated as Acts by a civilian government to bring them into conformity with the terminology of a civilian system of government ${ }^{35}$ ] combined with those of the EEZ Act ${ }^{36}$ invest in the federal government a 'complete' right of ownership over oil resources". 37 This 'complete' right is 'securely guaranteed' by section $44(3)$ of the present constitution of Nigeria, ${ }^{38}$ thus:

"Notwithstanding the foregoing provisions of this section [providing against compulsory acquisition of property without the payment of adequate compensation] the entire property in and control of all minerals, mineral oils and natural gas in, under or upon any land in Nigeria or in, under or upon the territorial waters and Exclusive Economic Zone of Nigeria shall vest in the government of the federation and shall be managed in such manner as may be prescribed by the national assembly."39

It might have been observed that the above provisions are silent on the issue of ownership of land; yet oil is entrapped in land and cannot be exploited without access to (or acquisition of) land. This leads us to an inquiry into the ownership of land before the enactment of the LUA and how this affected oil exploitation.

\subsection{Land tenure before 1978}

Before 1978 Nigeria did not have a uniform land tenure system. In the southern states of the federation, there was a dual system of land tenure, namely: customary ${ }^{40}$ land tenure system and land tenure under the received English law (sometimes called statutory land tenure system). The customary land tenure system varied from one community to the other,

35

36

37

38

39

40

For authoritative discussions of the customary land tenure of the various peoples of Southern Nigeria, see: A.K. Ajisafe, The Laws and Customs of Yoruba People, George Routledge and sons Ltd, London, 1924; Lloyd, Yoruba Land Law, Oxford University Press, Oxford, 1962; Coker, Family Property Among the Yorubas, Sweet \& Maxwell, London, 1966; Green, Land Tenure in an Igbo Village (n.d.); Chubb, Ibo Land Tenure, $2^{\text {nd }}$ ed., Ibadan University Press, Ibadan, 1961; Meek, Land Tenure and Administration in Nigeria and Cameroons, H.M.S.O., London, 1957. 
although some common legal principles are identifiable. In the case of the northern states of Nigeria, there was a system of 'public ownership' of land under a colonial statute ${ }^{41}$ which was retained and re-enacted after independence. ${ }^{42}$ The result is that before 1978 Nigeria had a plural land tenure system. A discussion of the 'statutory' land tenure system and the northern Nigeria 'public' land ownership system are not relevant to us here; ${ }^{43}$ we are here concerned only with the indigenous land tenure system of the people of southern Nigeria where the Niger Delta people are located.

It is beyond dispute that customary land tenure system is based on the native laws and customs of the various peoples of southern Nigeria. Although customs varied from place to place, ${ }^{44}$ studies have shown that some common legal principles are discernible. In the locus classicus of Amodu Tijani v. Secretary, Southern Nigeria ${ }^{45}$, the Privy Council stated the basic legal principle of customary land tenure in the following words: ${ }^{46}$

"The next fact which it is important to bear in mind in order to understand the native land law is that the notion of individual ownership is quite foreign to native ideas. Land belongs to the community, the village or the family, never to the individual. All the members of the community, the village or family have an equal right to the land, but in every case the Chief or Headman of the community or village, or head of the family, has charge of the land, and in a loose mode of speech is sometimes called the owner. $\mathrm{He}$ is to some extent in the position of a trustee, and as such holds the land for the use of the community or family. He has control of it, and any member who wants a piece of it to cultivate or build upon, goes to him for it. But the land still remains the property of the community or family. He cannot make any important disposition of the land without

Land and Native Rights Ordinance 1910. This law made all the rights exercisable in respect of native lands subject to the control and disposition of the colonial governor. The lands were held and administered for the use and common benefit of all the natives (defined as people of Northern Nigeria only), and no valid title could be created without the consent of the governor.

As Land Tenure Law 1962.

There is a voluminous literature on Nigerian Land Law. For authoritative discussions, see the following standard works: Elias, Nigerian Land Law, $4^{\text {th }}$ ed., Sweet \& Maxwell, London, 1971; Olawoye, Title to Land in Nigeria, Evans Brothers Limited, London, 1974; James, Modern Land Law of Nigeria, University of Ife Press, Ife, 1973; Okany, Nigerian Law of Property, Fourth Dimension Publishers, Enugu, 1986; Smith, Practical Approach to Law of Real Property in Nigeria, Ecowatch Publications (Nigeria) Limited, Lagos, 1999.

See Otogbolu v. Okeluwa (1981) 6-7 S.C. 99, at 115-6; Dilibe v. Nwakozor [1986] 5 N.W.L.R. (part 41) 315, at 331.

This was a judicial approval of a statement made by Rayner, C.J. in the Report of Land Tenure in West Africa, 1898. Before the West African Lands Committee a witness (Gboteyi, the Elesi (chief) of Odogbolu) had testified: "I conceive land belongs to a vast family of which many are dead, few are living and countless members are still unborn." See the Committee's Report. 
consulting the elders of the community or family, and their consent must in all cases be given before a grant can be made to a stranger." 47

Although the accuracy of the above statement has been severally challenged by different scholars, ${ }^{48}$ it would appear that there is an agreement that the traditional basis of customary land tenure is "common ownership" (in fee simple/absolute title), whether it is within a family or a community. ${ }^{49}$ This is one of the distinctive features of indigenous land tenure system. Another distinctive feature lies in the role of management and control entrusted with the Headman of the community or village; ${ }^{50}$ nobody, not even a member of the community or family, can make use of any portion of the community/family land in any way whatsoever without the consent of the Headman of the community.

Some scholars claim that before the enactment of the LUA this position was well-respected by everybody, including officers of government, right from the colonial era. ${ }^{51}$ So that, with respect to oil operations, although oil resources were vested in the state and the oilbearing/land-owning communities/families did not participate in farming out the resources to the oil companies, yet the oil prospecting and production companies entered upon the affected lands only after reaching an agreement with the land-owning communities/families on the amount of compensation (for any damage to surface rights- e.g. farm crops or building) and compensation (annual rent for the use of the land in its intrinsic state or other corporeal hereditaments) to be paid to the communities or families. ${ }^{52}$ According to one observer, any money received by the Headman on behalf of a community land must be shared within the community. ${ }^{53}$ In this way, oil-bearing communities had some form of participation in the exploitation of oil deposits in their lands.

At 404.

Elias, supra n. 43, at p. 74; Coker, supra n. 40, at p. 29; Utuama, Nigerian Law of Real Property: An Introduction, Shaneson Limited, Ibadan, 1989, p. 6. In Balogun v. Oshodi (1931) 10 N.L.R. 36 (decided 10 years after Amodu Tijani case) Webber, J. pointed out that the notion that individual ownership is quite foreign to native ideas has disappeared with the process of time, due to the spread of English ideas.

Omotola, The Land Use Act and Customary Land Tenure, (1982) Nigerian Current Law Review 55 , at 56 .

Ibid.

Ajomo, supra n. 17, at p. 339; Frynas, Oil in Nigeria: Conflict and Litigation between Oil Companies and Village Communities, Transaction Publishers, New Brunswick/London, 2000, at p. 75.

53 Ajomo, supra n. 17 , at p. 339.

Frynas, supra n. 51, at p. 73. 
It is significant to note that the native conception of land, unlike the statutory position of Nigerian law, includes mineral oils as part of the land. ${ }^{54}$ As one authority puts it, "the exclusive use and enjoyment of the land usually carried with it full rights to minerals, subject of course to the requirements of the prevailing custom and the relation of the particular occupier to the land; land usually included minerals". 55 Perhaps this explains why the Ogoni people of the Niger Delta boycotted a presidential election in 1993; they had argued that "Ogoni should not give legitimacy to a president who would swear to uphold a constitution that dispossessed Ogoni people of their natural rights". 56

\section{Land tenure and the Land Use Act}

The LUA was enacted in 1978 by a military government. It replaced the pre-existing plural land tenure system in Nigeria, thus bringing uniformity into the Nigerian land tenure system. Its target was the reform of the customary land tenure system which was considered a clog to development efforts. ${ }^{57}$ According to a government statement, "at present it is not only the individual who wants to build his or her house that is facing difficulties in finding a suitable land; the local, state and federal governments are also inhibited by problems placed in their way in acquiring land for development. ${ }^{, 58}$ However, being a law issued by a dictatorship it did not enjoy the benefit of robust debate in the legislature.

Moreover, although the Federal Military Government had set up a Land Use Panel to study the customary system of land tenure and make appropriate recommendations for reform,

Although there is no agreement on the question whether the English principle quicquid plantatur solo solo cedit is part of customary. For the conflicting views, see Onwuamaegbu, Nigerian Indigenous Land Law, in: Elias et al. (eds.), African Indigenous Law, Government Printer, Enugu, 1975, p.340, at pp. 352-4. See also Coker, supra n. 40, at p. 40.

Elias, supra n. 43, at p. 34. See also Price, Land Tenure in the Yoruba Provinces, para. 29.

Quoted in Naanen, supra n. 21, at p. 70.

57 See Adebgoye, The need for Land Reform in Nigeria, (1967) 9 Nigerian Journal of Economic and Social Reform, 339-350. Also making a case for land reform, Famoriyo has argued that "the problems may be considered as institutional barriers to development and stem largely from the failure to intervene in order to direct and streamline the customary tenure system so that it could become more conducive to economic development. If there has been objective intervention the result could conceivably have been the existence today of a powerful, dynamic and flexible land tenure system making a positive contribution to Nigeria's agricultural development... The complexity of the land tenure system in Nigeria shows that it is a single aspect of Nigeria's agrarian structure. It clearly requires intervention at both state and local levels..." Famoriyo, Some Problems of Customary Land Tenure, (1973) Land Reform, Land Settlement and Co-operatives, 2, 111. See also the Second and Third National Development Plans, 1970-74 and 1975-80, respectively (Federal Ministry of Economic Development, Lagos, 1970 and 1975 respectively).

See Report of the Land Use Panel, 1977, 5. 
available evidence shows that it acted against the recommendations of the majority members of the Panel; ${ }^{59}$ the Panel could not agree on one Report and so the Report contains a 'majority position' and a 'minority position'. The 'Majority Report', endorsed by the Panel's Chairman, ${ }^{60}$ was against either the nationalization of land or the extension of the prevailing land tenure system of the northern states to the country as a whole. On the contrary, the 'Minority Report' (which the Federal Military Government accepted) canvassed land nationalization in the manner of the prevailing system in the northern states. $^{61}$

As has been seen above, the mischief of the customary land tenure system which was sought to be reformed lies in the difficulties in land acquisition for developmental purposes. But available evidence indicates that "the government had often compulsorily acquired land for oil companies before 1978 under the so-called power of 'eminent domain', which gave it power to seize private property for public use." ${ }^{62}$ Right from time, the federal government of Nigeria had considered oil operations as serving the public 'interest'. Hence, as Frynas points out, the power of 'eminent domain' is specifically provided for in the Oil Pipelines Act and in the Petroleum Regulations 1969 (made pursuant to the Petroleum Act 1969). ${ }^{63}$ Consistent with justice, these laws provide for the payment of adequate compensation to the person or community whose land is acquired. ${ }^{64}$ Any dispute over the issue of compensation was determined by the courts. For example, in Nzekwu v. Attorney-General, East-Central State ${ }^{65}$, the plaintiffs sued the government for compulsory acquisition of their land; they had demanded higher compensation than they were actually offered. ${ }^{66}$ It will later be seen how the LUA has affected this position.

Francis, For the Use and Common Benefit of all Nigerians: Consequences of the 1978 Land Nationalization, Africa 54(3) 1984, 5-27, at p. 7. This article analyses the provisions of the LUA, with particular reference to its effects on a peasant community in Yoruba-land; it was not concerned with issues relating to oil resources.

60

61

62

63

64 
Since its enactment ${ }^{67}$ the LUA has remained controversial and the subject of constant debate. ${ }^{68}$ Studies indicate that it is a complex piece of legislation with far-reaching consequences on different aspects of the pre-existing customary land tenure systems. Most of the impacts of this 'reformative law' 69 have received scholarly consideration; but the impact of the Act on the oil-bearing communities of the Niger Delta has not received any systematic academic consideration. As stated earlier, the object of this paper is to fill this gap. For our purposes, the critical question relates to the issue of ownership of land under the Act. The most relevant place to start on this issue is section 1 of the LUA, which provides as follows:

"Subject to the provisions of this Decree, all the land comprised in the territory of each state of the federation are hereby vested in the military governor of the state and such land shall be held in trust and administered for the use and common benefit of all Nigerians in accordance with the provisions of this Decree."

pose' as defined in the Public Lands Acquisition Law of Western Nigeria 1959. It has been argued that the precedent established by this case no longer applies since the enactment of the Land Use Act in 1978. Frynas, supra n. 51, at p. 77. Cf. Ajomo, supra n. 17, at p. 338.

On the occasion of the Decree's announcement the Head of State articulated its purpose thus: "The main purpose of this Decree is to make land for development available to all including individuals, corporate bodies, institutions and governments. When taken in conjunction with other measures we have adopted and other measures to be adopted, it will be evident that fast economic and social development at all levels and in all parts of the country is our main consideration." Reform in Nigerian Land Tenure Structure (Address to the Nation on 29 March 1978, by His Excellency Lt. General Olusegun Obasanjo, Head of the Federal Military Government, Commander-in-Chief Of the Armed Forces), Federal Ministry of Information, Lagos, 1978, p. 5.

There is a voluminous literature on the Land Use Act. See, for example: Omotola, Essays on the Land Use Act, Lagos University Press, Lagos, 1980; Omotola (ed.), The Land Use Act: Report of a National Workshop, Lagos University Press, Lagos, 1982; Adigun (ed.), The Land Use Act: Administration and Policy Implication, Lagos University Press, Lagos, 1991; James, Nigerian Land Use Act: Policy and Principles, University of Ife Press, Ile-Ife, 1987; Osipitan, Public Law and the Land Use Act, in: Omotola (ed.), Issues in Nigerian Law, The Caxton Press, Lagos, 1991, pp. 84-104.

The Land Use Act has been variously described as 'revolutionary', 'controversial', and 'impactful'. In L.S.D.P.C. v. Foreign Finance Corporation (1987) 1 N.W.L.R. (part 50) 413, at 460, Kolawole, J.C.A. observed: "The Land Use Act 1978 has revolutionalized the land tenure system in the southern states of this country..." The same description of the Act was made by Obaseki, J.S.C. in Savannah Bank (Nig.) Ltd. v. Ajilo (1989) 1 N.W.L.R. (Part 97) 305, at 315; Adeoye sees the LUA as 'controversial'. Adeoye, Some Aspects of the Land Use Act, (1982) Nigerian Current Law Review 312, at 314. See also Ajomo, Ownership of Mineral Oils, at 330; and Irikefe, J.S.C. believes "the Land Use Decree is indisputably the most impactful of all legislation touching upon the land tenurial systems of Nigeria before and after full nationhood". See Nkwocha v. Governor of Anambra State (1984) 6 S.C. 362, at 363. All these indicate the active debate scholars and jurists are engaged in over the provisions of the LUA, and demonstrate the controversial nature of the Act - promulgated by a military dictatorship, and against the majority opinion of a Panel set up by itself to study and make recommendations on land reform. 
There is no agreement on the interpretation of this provision. Some of the views considered here are only representative of the diversity of views on its meaning. One view is that by the tenor of this provision individuals and communities have been divested of their ownership rights over land without transferring it to anyone, save that the governor is made trustee of it; "one now finds it difficult to know where ownership of land lies or whether there is now any kind of ownership of land still existing." another view which sees the governor of a state as the new owner of all lands comprised in the territory of the state: "Section 1 of the Act takes away absolute ownership of land from the citizens and vests it in the governor". 71 Notwithstanding their difference, both views agree that customary landowners have lost their pre-existing rights under customary land tenure system.

There is some measure of support for both views, even in judicial decisions, particularly for the second one. Nevertheless the second view has been obliquely attacked. It has been contended that the "vesting provision" (section 1) is ineffective without first divesting existing owners of their absolute title. ${ }^{72}$ This argument relies on the authority of the decision in Sir Adetokunbo Ademola v. John Ammo, ${ }^{73}$ where the court held that no certificate of occupancy can be validly issued in respect of a land which is in the possession of another without first revoking the title of the original occupier. The implication of this argument is that customary owners are still holding land under customary land tenure system, as section 1 of the LUA did not first divest them of their original title. This argument was judicially approved in the case of Aina Co. Ltd. v. Commissioner for Lands and Housing, Oyo State. ${ }^{74}$ After rejecting the contention of a state counsel that the land in dispute had become vested in the state by virtue of the provisions of the LUA, the learned judge observed:

"The fact that the defendants [Oyo state Government] are now showing an intention to acquire plaintiff/company's land by means of [Notice of Acquisition] shows beyond reasonable doubt that the property in dispute was not vested in the governor... since $1^{\text {st }}$ October 1979 we had returned to the land tenures that obtained in Oyo state prior to the enactment of the Land Use Act; only we were slow to realize that fact." 75 
There is a line of judicial decisions which contradicts the above pronouncement, and supports the view that state governors are now the new owners of land. Two cases may be used to illustrate this fact. The first case is Akinloye v. Oyejide, ${ }^{76}$ where the judge expressed the following view:

"In my humble opinion...the use of the word 'vested' in section 1 of the Land Use Act 1978 has the effect of transferring to the governor of a state the ownership of all land in that state... On the literal reading of the Land Use Act 1978, I am of the view, and I so hold, that the intelligible result is to deprive citizens of this country of their ownership in land and vest same in the respective governors. The presumption that the law maker does not desire to confiscate the property, or to encroach upon the rights of persons is, in my view, rebutted on the clear and unambiguous provision of the Act."77

The other case, ${ }^{78}$ which was a decision of the Court of Appeal, ${ }^{79}$ appears even more direct on the effect of the LUA on customary land tenure system. Speaking on this issue, their Lordships said:

"The ownership and title to lands in Nigeria is now vested in the governors of the various states of the federation for the benefit of all Nigerians as a whole. Communal and individual title ownership (sic) to land is now a thing of the past. The conception of land being in the family for the past, present and future members of it is no longer valid...The freedom of alienation and dealing with the land which was vested in the heads of the family or traditional authorities is now vested in the government...,80

The confusion engendered by these conflicting views, particularly in judicial decisions, is apparent. It was under this situation that the Supreme Court (the highest court of the country) moved in the case of Abioye v. Yakubu ${ }^{81}$ to reconcile the conflicting views. The central question in that case was "whether, having regard to the provisions of the Land Use Act 1978, customary owners are entitled to be granted declaration of title to a parcel of land

Suit No. HCJ/9A/81 of 17/7/81 (reported in Omotola, Cases on the Land Use Act, Lagos, 1983, p. 146.

77

At pp. 149-150.

L.S.D.P.C. v. Foreign Finance Corporation (1987) 1 N.W.L.R. (Part 50) 413.

In the Nigerian judicial hierarchy, the Court of Appeal is the intermediate court between the High Courts (States and federal) and the Supreme Court (which is the highest court of the country). Together these courts constitute the superior courts of records of Nigeria. Unlike other federal states, the Court of Appeal and the Nigerian Supreme Court have country-wide appellate jurisdiction on all issues.

At p. 444. Adeoye disagrees with this statement and urges the "need to be cautious in awarding the Land Use Act a sweeping effect". Adeoye, The nature of the right of occupancy under the Land Use Act, 1978, in: Omotola (ed.), Issues in Nigerian Law, supra n. 68, p. 105, at p. 114. 
against their customary tenants. ${ }^{, 82}$ After elaborate proceedings in which the court had sought the assistance of senior lawyers as amici curie, the court held, inter alia, as follows:

- that the Land Use Act has removed the radical title in land from individual Nigerians, families, and communities and vested the same in the governor of each state of the federation in the federation in trust for the use and benefit of all Nigerians (leaving individuals, etc., with 'rights of occupancy'); and

- that the Act has also removed the control and management of lands from family and community heads/chiefs and vested the same in the governors of each state of the federation (in the case of urban lands) and in the appropriate local government (in the case of rural lands).

It should be observed that this decision accords with the Court of Appeal decision in the case stated above. It also accords with an earlier decision of the Supreme Court where the court had pointedly said:

"This appeal deals with the interpretation of some of the provisions of the Land Use Act 1978. Since the promulgation of the Act by the military administration of General Obasanjo in 1978, the vast majority of Nigerians have been unaware that the Act swept away all the unlimited rights and interests they had in their lands and substituted them with very limited rights and rigid control of the use of their limited rights by the ... governors ... This appeal ... will bring the revolutionary effect of the act to the deep and painful awareness of many ... Section 1 of the Act has made no secret of the intention and purpose of the law. It declared land in each state of the federation shall be vested in the ... governor of each state." 83

Now, what is the "revolutionary effect of the LUA" which has been brought to the "deep and painful awareness" of the Niger Delta people? This is the subject of the next section.

Per Bello, C.J.N., at 184. A 'customary tenant' is a tenant from year to year liable under customary law to pay rents or tribute to the landlord for the use of the land and barred from alienating the land without consent or disputing the title of the landlord. (Ibid, at 225). Although oil companies recognised oil-bearing communities as their landlords and paid an agreed 'annual rent', the relationship was never that of landlord and customary tenant, although they share many features; it was more of that of English tenancy.

Savannah Bank (Nig.) Ltd. v. Ajilo, supra n. 69, at 214 per Obaseki, J.S.C. Cf. Ojemen $v$. Momodu II (1983) 3 S.C. 173, at 214, where Obaseki, J.S.C. after rejecting the appellants counsel's submission that since the Land Use Act vested all lands in the state in the governor of the state from 29 March 1978, the Irrua community (respondents) from that date ceased to have interest in the land in dispute, said: "As the Irrua community is entitled to own property [land], there is nothing in the [Land Use Act] to prevent the community from applying for the issue of a certificate of occupancy by the appropriate authority...." (Italics mine). 


\section{Impact of the Land Use Act on the Niger Delta People}

It has been observed that: "It is... beyond the direct powers of the legislators to determine the impact of their laws, for the effects of legislation are conditioned by a multitude of agencies and processes only some of which fall within the purview of the state. The distinction between legislative intention and legislation's effects is an impact of the disjunction between the national and the local; between the state's pretensions and the community's impermeability; or, in their normative aspects, between 'law' and 'custom'., 84

In any case, where a legislation produces an unintended effect or works hardship, an occasion arises for the repeal or amendment of the legislation in order to end the unintended result or injustice. As we shall see presently, it seems the occasion has arisen for the repeal of the LUA. For convenience, the impact of the LUA on the Niger Delta people will be discussed under two sub-heads, viz: (1) Loss of power by traditional authorities; and (2) Loss of right to compensation. These will be considered in turn.

\subsection{Loss of power by traditional authorities}

As has been pointed out above, one of the most important features of customary land tenure system is the power (and right) of management and control entrusted with the community's Headman or chief (usually the oldest surviving male member of the community). As manager, it is he who allocates portions of the land to members of the community and to non-members/strangers ${ }^{85}$ for their personal use, usually for farming purposes or for building residential houses; he protects the land against all intruders and receives any compensation or other money on behalf of the land. In allocating portions of the land to members of the family, he is usually guided by the requirements of fairness and justice; he ensures that nobody is cheated. As it relates to oil operations, prior to 1978, oil companies sought and obtained the consent of the Head of a community upon terms to pay adequate compensation for any damage to surface rights and compensation (annual rents) for the use of their land.

It is important to note that if any member had any complaint against another member or a stranger, particularly as it relates to farmland (the people are traditionally subsistence farmers and fishermen) he brought it before the Headman who looked into the matter and settled it. It appears sometimes the complaint related to damage arising from oil spill 
(which is a common phenomenon in the Niger Delta). Available information shows that the local people invariably gave power of attorney to their Headman to pursue their claims ${ }^{86}$ (which usually included damage to surface rights and to the land in its intrinsic state). Before 1978 successful 'individual claims' were paid to the beneficiary while 'common claims' were shared amongst members of the community in a way that ensures justice for all. $^{87}$ This way, the traditional authorities helped to maintain social cohesion.

Now, as Abioye's case indicates, the traditional authorities (Chiefs/Headmen) have lost their traditional rights and powers of management and control of land. This is the direct result of section 2(1) of the LUA which provides that

"as from the commencement of this Act"-

(a) all land in urban areas shall be under the control and management of the military governor [now interpreted to include civilian governors] of each state;

(b) all other land shall, subject to this Decree [Act], be under the control and management of the local government within the area of jurisdiction of which the land is situated."

Having regard to the important role of traditional authorities as earlier stated, it is hardly surprising that at a very early stage the traditional authorities saw the Act as "an attempt to bring chaos into the country". 88 The implication of this statement is that the LUA has the potential of causing social disruption and disorder in community life. This is true because available evidence indicates that among the native people of southern Nigeria the subject of land is a sensitive. ${ }^{89}$ For instance, with respect to the Yoruba people of South-western Nigeria, it has been observed long ago that "there is no subject in which the Yoruba is more sensitive than that of land. These normally quiet and submissive people can be roused into violent action of desperation if once they perceive that it is intended to deprive them of their land." 90 This observation is equally true of the Niger Delta people. ${ }^{91}$ In fact, only recently, the representatives of four Ijaw communities of the Nigeria Delta indicated in a signed statement that they are ready to defend their 'God-given right' to their land "with our blood". 92

Records in the office of Ebeku \& Ebeku (Legal Practitioners and Consultants), Port Harcourt, Nigeria.

Personal interview with some traditional authorities in Ekpeye-land, Rivers State (February, 2000).

Daily Times, 8 April 1978.

89

Green, Land Tenure in an Ibo Village, 1941, p. 2.

90

Johnson, The History of the Yorubas, 1921, p. 96.

91

See Kaiama Declaration, 1978.

92

See Annual Report of the Civil Liberties Organisation, Lagos, 1997, 205-6. 
Today, as the traditional authorities have lost their rights and powers, and therefore unable to effectively manage complaints, ${ }^{93}$ violent actions and social disharmony have become endemic in the Niger Delta. ${ }^{94}$ From all indications, this is the direct result of the loss of their land rights and is directly related to the injustice of loss of right to compensation which is the subject of the next section.

\subsection{Loss of right to compensation}

Compensation may be said to be a suitable payment in return for loss or damage. This can be achieved by way of negotiation, arbitration or litigation. ${ }^{95}$ Perhaps it is in recognition of the need for recompense that the Petroleum Act ${ }^{96}$ (under which compulsory acquisitions of land for oil operations - by the power of eminent domain - was made prior to the enactment of the LUA) made provisions for the payment of adequate compensation to owners of land

Some members of the communities suspect the incapacitated traditional authorities of collaborating with the government and the oil companies to oppress and cheat them or being too passive. See Tempo Newsmagazine, June 1999.

Violent actions have never been associated with the Niger Delta people; they had been a peaceful, organised and friendly people. Before the imposition of colonialism in late $19^{\text {th }}$ century, they had engaged in friendly relations and trade with Europeans for centuries, especially between the $15^{\text {th }}$ and $18^{\text {th }}$ centuries. It was their trade in palm oil that earned them their colonial name 'Oil Rivers'. See Dike, Trade and Politics in the Niger Delta, Oxford University Press, Oxford, 1956.

Negotiation and arbitration are peaceful ways of settling compensation claims. But often the oil multi-national giants refuse or fail to settle claims by either of these means, even when they do not dispute that some damage has been done to the property of the claimants. In nine out of ten cases, the victims are too poor to pursue their claims in court, and so remain without compensation. Even in the rare cases when the victims go to the court their resources to fight their cause cannot match those of the oil multi-nationals and often they lose their case on technical grounds. The recent case of The Shell Petroleum Development Company (Nig.) Ltd. v. Ambah [1993] 3 N.W.L.R. (Part 593) 1, exemplifies this point. The oil company had refused to negotiate compensation with a family whose property had been damaged by the activities of their agents. The victims went to the court to seek justice, but their case tethered at the Supreme court on procedural obstacles - the Supreme Court overturned their victory at both the trial court and the Court of Appeal, purely on technical grounds (insufficiency of pleadings by their counsel). In his judgement, the trial court had observed: "I shall not conclude this judgement without saying that the defendant ought not to allow this case to go to court. It is a matter they ought to have negotiated and settled out of court as it appears to me that they have no defence whatsoever to this action." (Ibid, at p. 9). Under the Land Use Act, any dispute over compensation for land compulsorily acquired for the activities of oil companies is to be settled by an administrative body and not by the court. See sections 30 and 47(2). 
compulsorily acquired for the purposes of oil operations. ${ }^{97}$ Besides, as earlier noted, prior to 1978 where land was not compulsorily acquired by the government and an oil company had to negotiate with community land owners for access to land for oil operations, it settled the amount of compensation (annual rent) it had to pay to the community for the use of the land in its intrinsic nature (oil operations may result to a total loss of use of the affected portion of land by the land owners). Additionally the oil company had to pay compensation for any damage to surface rights (e.g. farm crops or building). In this case, compensation must be fair and adequate ${ }^{98}$ and its payment is consistent with fairness and justice. ${ }^{99}$

To put it metaphorically, payment of compensation is a soothing balm to oil-bearing/landowning communities. Significantly, any dispute over the issue of compensation was decided by a court of law. ${ }^{100}$ On the whole, oil-bearing communities had some sense of relief when compensation is paid to them. With regard to payment of compensation in the sense of annual rent, they additionally felt some sense of participation in the exploitation of oil resources located in their lands (it should be remembered that by statutory provisions they are not entitled to any rent or royalty for the exploitation of oil). Moreover oil companies recognised oil-bearing communities as their landlords and this carried with it some minimal 'privileges': employment of some community members as security-men for oil installations and the award of small contracts (mostly the maintenance of oil pipelines by keeping them free from weeds). ${ }^{101}$

Since the enactment of the LUA in 1978, acquisition of land is now done under the Act. ${ }^{102}$ The Act provides for the revocation of a right of occupancy by the governor of a state for "overriding public interest", in that it is required for mining purposes or oil pipelines or for

97

98

99

100

101

See also section 11(5) of the Oil Pipelines Act 1956 (Cap 338 of the Laws of the Federation of Nigeria 1990 Edition).

See paragraph 36 of schedule 1 to the Petroleum Act. See further, Shell Petroleum Development Co. v. Farah [1995] 3 NWLR (Part 382) 148, at 198. Also, Adewale, Oil Spill Compensation Claims in Nigeria: Principles, Guidelines and Criteria, (1989) J.A.L. 91, at p. 93.

See generally Horn v. Sunderland (1941) 1 All E.R.166; (1941) 1 All E.R. 480 (Appeal).

Ekemike, Understanding the Nigerian Land Use Decree: Its Uses and abuses, Kems, Benin-city, 1978. See also, Aghenghen v. Wahgoreghor (1974) All NLR 74; Okwusa v. Adizua (1977) 1 IMSLR 217; Nzekwu v. Attorney-General, East-Central State (1972) NLR 543.

Ironically some of these 'favours' were used by the oil companies to divide and rule the people. Even so, today, contractors are known to have been brought outside the oil-bearing communities to do these menial jobs.

102

Section 31 of the Land Use Act provides: "The provisions of the Public Lands Acquisition (Miscellaneous Provisions) Act shall not apply in respect of any land vested in , or taken over by, the Governor or any Local Government pursuant to this Act or the right of occupancy to which is revoked under the provisions of this Act but shall continue to apply in respect of land compulsorily acquired before the commencement of this Act." See also section 48; Governor of Kaduna State v. Dada [1986] 4 N.W.L.R. (part 38) 687. 
any purpose connected therewith. ${ }^{103}$ When this is done, the law provides for the payment of compensation to the 'holder' and 'occupier' "under the appropriate provisions of the Minerals Act ${ }^{104}$ or the Petroleum Act ${ }^{105}$ or any legislation replacing the same". ${ }^{106}$ Under section 77 of the Minerals Act, any person prospecting or mining shall pay to the 'owner or occupier, 107 of private land "such sums as may be a fair and reasonable compensation for any disturbance of the surface rights of such owner or occupier and for any damage done to the surface of the land upon which his prospecting or mining is being or has been carried on and shall in addition pay to the owner of any crops, economic trees, buildings or works damaged, removed or destroyed by him or by any agent or servant of his compensation for such damage, removal or destruction". ${ }^{108}$ The appropriate provision of the Petroleum Act is similar to this. ${ }^{109}$ Even so section 29(3) of the Act gives a discretion to the governor of a state to decide who receives the money (and possibly how it may be utilised). It would be recalled that under the prevailing customary land tenure system before 1978, any such compensation would be paid to the traditional authority of the community concerned for the benefit of the community. Quoted in extenso, section 29(3) provides:

"If the holder entitled to compensation under this section is a community the governor may direct that any compensation payable to it shall be paid-

to the community; or

to the chief or leader of the community to be disposed of by him for the benefit of the community in accordance with the applicable customary law; or

103

Sections 28 (1) and (2)(c). There are other grounds for revocation set out in the Act. See sections 28 and 29.

104

1946 (Cap 226 of the Laws of the Federation of Nigeria 1990 Edition).

105

1969 (Cap 350 of the Laws of the Federation of Nigeria 1990 Edition).

106 Section 29(2). Where revocation was done on any other ground, the 'holder' and 'occupier' shall be entitled to compensation "for the value at the date of revocation of their unexhausted improvements."

107 This expression conflicts with 'holder' and 'occupier' which is used in the Land Use Act. Unlike the Minerals Act, it would appear that the Land Use Act envisages the payment of compensation to two classes of persons. To this extent, this may be considered as a modification of the former. For the view that the compensation provision of the Minerals Act does not apply to oil operations, see Adewale, "oil spill compensation Claims in Nigeria: Principles, Guidelines and Criteria" [1989] J.A.L. 91, at 92. With respect, the view was misconceived.

108 From the tenor of section 28 of the Land Use Act - "If a right of occupancy is revoked for mining purposes or oil pipelines or for any purpose connected therewith" - it would appear that this provision is inapplicable to damage caused by oil operations; for then the land has already been 109 acquired for such purposes.

See paragraph 36 of schedule 1 to the Petroleum Act. 
into some fund specified by the governor for the purpose of being utilized or applied for the benefit of the community." 110

It would appear that this provision is a confirmation of the view held in some quarters that the governor of a state is the new owner of all the land comprised in the territory of the state. ${ }^{111}$ As could be observed, the provision speaks of holder and not owner (of a right of occupancy - new interest in land created by the LUA). The result is that, like oil rights, land rights are now vested in the state. This situation has been described by an observer as nationalization of land. In his words, "the meaning and effect of vesting all lands in the government is that private ownership is hereby abolished and the title of the former private owners transferred to the government." for land compulsorily acquired under the Act are now paid to the governor of the state concerned and not to the community Headman as before. ${ }^{113}$ In the result, the communities hardly receive any portion of the money paid or have any useful thing done for them out of the compensation. A source claims that state governors now feel communities are no longer entitled to compensation as of right since they no longer own any land. ${ }^{114}$ Maybe this is an aspect of the 'revolutionary effect of the LUA' on the oil-bearing, peasant communities of the Niger Delta which the Supreme Court alluded to in one of its decisions mentioned above.

Apart from compensation for land compulsorily acquired, the issue of compensation can also arise in the course of oil operations. For example, damage arising out of oil pollution.

110 Compare section 21 of the Oil Pipelines Act which provides: "Where the interests injuriously affected are those of a local community, the court may order the compensation to be paid to any chief, headman or member of that community on behalf of such community or that it be paid in accordance with a scheme of distribution approved by the court or that it be paid into a fund to be administered by a person approved by the court on trust for application to the general, social or educational benefit and advancement of that community or any section thereof."

111 See the section on Land Tenure and the Land Use Act, above.

112 Nwabueze, Nationalization of Land in Nigeria - Paper delivered at the annual Bar Dinner of the Nigerian Bar Association, Onitsha Branch, on 8 December 1984. In an earlier dictum in Nkwocha v. Governor of Anambra State, supra, Eso, J.S.C. had said "the tenor of the Land Use Act as a single piece of legislation is the nationalization of all lands in the country by the vesting of its ownership in the state, leaving the private individuals with an interest in land which is a mere right of occupancy" (at 404).

114 .

Ajomo, supra n. 17, at p. 338: "Compensation, sometimes called rent by the recipients, had from time belonged to individuals or communities, owners of land on which petroleum operations were being carried out. But because the LUA has vested the management and control of land in the governor, he now feels that is to him that the compensation should be paid rather than the community or the families who owned the land before the Act came into force... Recently some governors have cited the LUA as justifying this right being claimed by them". See also Frynas, supra $\mathrm{n}$. 51 , at p. 78. 
It is a notorious fact that oil operations (activities of the oil industry) involve the risk of oil pollution. As has been pointed out, "the threats of pollution are real. Their economic consequences are real. Their health consequences are real. There are sufficient data to make strong cases based on facts." ${ }^{, 15}$ In fact, studies suggest that the Niger Delta is a case study in pollution; there are all conceivable types of pollution in the Niger Delta. ${ }^{116}$ Of all, gas flare and oil pollution (arising from oil spill) appear to be the most serious. According to a recent World Bank report on the Niger Delta, "oil development can degrade the environment, impair human health and precipitate social disruptions.",117

When pollution occurs it is only fair and just that 'adequate compensation' ${ }^{118}$ should be paid to the victims. ${ }^{119}$ However, notwithstanding the great nuisance and health risks involved in constant gas flare ${ }^{120}$ (which is an aspect of oil pollution), there is no evidence that oil companies in Nigeria had ever paid compensation to the victims. The phenomenon and the evil of gas flare in the Niger Delta were admirably stated in a recent study ${ }^{121}$, thus:

"Gas flaring has been the most constant environmental damage because in many places it has been going on 24 hours a day for over 35 years. There are hundreds of gas flares throughout the Niger Delta. It affects plant life, pollutes the air, pollutes the surface water and as it burns, it changes to other gases which are not very safe. It also results in acid rain. With the pullout of Shell from Ogoniland, gas flaring has stopped in 4 of the 5 flow-stations. Where the gas flaring has stopped, people were able to see a difference

Josephs, Environ. Sci. Tech. 1: 525 (1967) - quoted in Hodges, Environmental Pollution, Holt, Rinehart and Winston, Inc., New York, 1973, vii.

116

117

Hutchful, supra n. 21, at pp. 113-140.

World Bank, Defining An Environmental Strategy For the Niger Delta, 1995, Vol. 1, 81 .
The expression 'Adequate compensation' means "just value of property taken under power of eminent domain payable in money. Market value of property when taken. It may include interest and may include the cost or value of the property in the owner for the purposes for which he designed it. Such only as puts injured party in as good a condition as he would have been if injury had not been inflicted". (Italics mine). See Shell Petroleum Development Co. v. Farah [1995] 3 NWLR (Part 382) 148, at 199.

119 See Paragraph 36 of schedule 1 to the Petroleum Act; section 11(5) of the Oil Pipelines Act 1956 (Cap 338 of the Laws of the Federation of Nigeria 1990 Edition). See also paragraph 23 of the Petroleum (Drilling and Production) Regulations 1969 (made under section 9 of the Petroleum Act 1969, Cap 350 LFN 1990 Edition).

"As a byproduct of oil production, Nigeria flares more gas than any other country in the would; most of it from the Niger Delta. About $88 \%$ of the associated gas is flared...Considering the low combustion efficiency of Nigerian flares $(80 \%)$ a large portion of the gas is vented mainly as methane...Based on the much higher global warming potential of methane...the significance of the Nigerian gas flares is considerable." Mofatt / Linden, Perception and Reality: Assessing Priorities for Sustainable Development in the Niger Delta, (1995) 24, Ambio 527, at p. 533. (Ambio is the Magazine of the Royal Swedish Academy of Sciences).

Robinson, supra n. 32, at p. 28. 
in their vegetation; farm yields are better than before. The people did not know what it was like to live without Shell. It is only now that the people in these areas can see what type of environmental devastation the gas flaring had been causing for the past 35 years...,122

In the case of oil pollution (arising from crude oil spill) scientific evidence has shown that it can cause long-lasting or permanent damage to the land itself (e.g. loss of fertility ${ }^{123}$ ). ${ }^{124}$ In which case it may represent a permanent or great loss of use to those who depend on it for their livelihood. ${ }^{125}$ Yet, according to sources, since the enactment of the LUA whenever the oil companies accept liability for oil spill, ${ }^{126}$ they only pay 'compensation' for any surface rights (like farm crops) and not for the land itself. ${ }^{127}$ "Meanwhile, the people would have suffered huge and untold losses. Apart from the health risks to which they are exposed by pollution, they suffer losses of economic activities. Fishing activity suffers as fish die

\section{At p. 28. See also Hutchful, supra n. 21 , at p. 118}

23 According to one observer, "oil-spill contamination of the top soil may render the soil unsuitable for plant growth by reducing the availability of nutrients (for example, nitrogen), or by increasing toxic contents in the soil; heavily contaminated soil may remain unusable for months or years until the oil has degraded to tolerable levels." Odu, Degradation and Weathering of Crude Oil under Tropical conditions, 1981 (cited in Hutchful, supra n. 21, at p. 118).

See generally, Gundlach / Hayes / Getter, Sensitivity of Coastal Environments to Oil Spill, 1981 (cited in Hutchful, above, at p. 116). See also, Hutchful, above, at p. 118.

Studies following the 1972 oil spill at Shell's Bomu-11 field, which affected 242.8 hectares of farming land close to settlements, indicated that "whereas the less highly polluted soils were returned to production in less than one and half years, the heavily contaminated soils took several years to recover." Hutchful, above, at p. 118.

126 Almost invariably oil companies deny responsibility for oil pollution, alleging sabotage by members of the community. They hardly agree that equipment failure could have been responsible for oil spills. But available evidence indicates that equipment failure is a major cause of oil spills in Nigeria. For instance, in a study in 1981 it was found that between 1976 and 1980, Nigeria recorded a total of 784 spills involving 1336875 barrels of crude oil, out of which equipment failure accounted for $50 \%$ of the spills. Awobajo, An analysis of Oil Spill incidents in Nigeria: 1976-1980 - Paper presented at the seminar on the Petroleum Industry and the Nigerian Environment, organised by the NNPC at the Petroleum Training Institute, Warri, 9-12 November 1981. A recent statement by Shell Petroleum Development Company of Nigeria (SPDC) indicates that there is no basis for denying the great role of equipment failure in frequent oil spills in the Niger Delta: "The challenge that SPDC faces is that a major part of its infrastructure for many of its largest fields were built in the 1960s and 1970s, using the best oil industry practices available at the time. Many of them were due for refurbishment and upgrade in the mid 1980s to meet current standards. However, this coincided with the period of collapse in oil prices and revenues (...) although some maintenance programmes slipped then, the gap between previous standards and those of the present day are fully recognised. SPDC is addressing this through an upgrade programme of facilities-flowlines, flowstations and terminals." See http://www.shellnigeria.com/ shell/devastation_rhs.asp.

Constitutional Rights Projects: Land, Oil and Human Rights in Nigeria's Delta Region, 1999, 16. See further Adewale, supra n. 107, at p. 95 (footnote 31). 
from pollution or migrate elsewhere. Farmers are dislodged from the soil they have been using for so many years and all of these losses are not adequately addressed by either the compensation paid or the system of paying compensation.,"128

Their contention is that "the communities own neither the surface of the land nor what is beneath". ${ }^{129}$ This attitude is typified by a recent statement by Shell oil company: "As a responsible Nigerian company SPDC [Shell Petroleum Development Company] obeys the laws of the country, one of which is the Land Use Decree of 1978 which vests ownership of all land with the government (sic)...Today we give compensation for the surface rights of all land acquired for our use and for damage...from subsequent activity, including oil spills..." 130 The implication of this statement is that the present attitude of the oil companies is informed by the provisions of the LUA. A source indicates that even the socalled 'compensation' for surface rights does not meet the requirements of fairness and justice - it is not fair and adequate. ${ }^{131}$

It appears the impact of the LUA on the Niger Delta people ranges beyond the two 'broad' issues considered above. Perhaps the full amplitude of injustice which the LUA is visiting on the Niger Delta people would be better appreciated if the following facts are considered: ${ }^{132}$

Disputes over quantum of compensation payable for land compulsorily acquired under the Act or other issues connected therewith are to be settled administratively ${ }^{133}$ (and not by the courts as before ${ }^{134}$ ) by a statutory body called Land Use and Allocation Committee, ${ }^{135}$

Constitutional Rights Projects, above, at 16.

Ibid.

130

Quoted in Robinson, supra n. 32, at p. 37.

131 "If the claim is in respect of farmland...each crop is given a value. Although the value given to each crop is approved by the government, this value also depends on a number of factors. This includes the age of the crop, the size of the crop, i.e. whether it is young, medium or mature...It means that the value given to these crops is not fixed. There is the need to review the mode of assessing these crops. What should be given to the claimant is the amount he would have obtained from the crops if it had matured and not been damaged by the oil spill". (Italics mine). Adewale, supra n. 107, at p. 96. See also Okigbo, Report of the Presidential Commission on Revenue Allocation, Vol.111, Federal Government Printer, Apapa, Lagos, 1980.

132 Although some of the factual situation stated here may not be the direct result of the enactment of the LUA, it is arguable that the LUA presents additional burden to the people.

See Sections 2(2)(c ) and 30. It appears these provisions were borrowed from or influenced by section 78 of the Minerals Act (Cap 226 LFN 1990).

134 Section 11(5) of the Oil Pipelines Act provides that if the amount of compensation to be paid to a land owner is not agreed between him and an oil company, "it shall be fixed by a court in accordance with Part IV of this Act". See also Ekemike, Understanding the Nigerian Land Use Decree: Its uses and abuses, Kems, Benin-city, 1978. 
members of which are appointed by the appropriate state governors (who are known to be in alliance with the multi-national oil companies and against the communities ${ }^{136}$ ). There is no statutory provision to ensure the independence and impartiality of these bodies. In fact, a provision indicates that they are under the control and direction of the governors: "The Land Use and Allocation Committee shall,... subject to such directions as may be given in that regard by the governor... have power to regulate its proceedings". ${ }^{137}$ Perhaps ex abundanti cautela section 47(2) of the Act expressly ousts the jurisdiction of the courts: "No court shall have jurisdiction to inquire into any question concerning or pertaining to the amount or adequacy of any compensation paid or to be paid under this act."

Oil-bearing communities of the Niger Delta are traditionally fishermen and farmers and depend on the land for their livelihood. Oil pollution (which occurs frequently ${ }^{138}$ ) can cause serious or permanent damage to the land itself. There is evidence that farm yields are now poor in the region because of the effect of pollution on the land. As has been stated, one commentator has noted, "gas flaring has been associated with reduced crop yield and plant growth on nearby farms, as well as disruption of wildlife in the immediate vicinity.",139

Several years of unsustainable exploitation of oil has devastated the local environment, thereby depriving the people of the optimum use of their lands and waters. This point is captured by this observation: "Environmental pollution from the oil industry has had farreaching effects on the organization of peasant life and production. In addition to the effects of spills on mangroves...spills of crude, dumping of by-products from exploration, exploitation and refining operations (often in freshwater environments) and, overflowing of oily wastes in burrow pits during heavy rains has had deleterious effects on bodies of

The relevant section provides that "where there arises any dispute as to the amount of compensation...such dispute shall be referred to the appropriate Land Use and Allocation Committee". (Section 30).

See Osaghae, The Ogoni Uprising: Oil politics, Minority Agitation and the Future of the Nigerian State, African Affairs (1995), 94, p. 325, at p. 342. See further Frynas, supra n. 59, at pp. 54-58.

Section 2(4). As long as the governors are in alliance with the oil companies, it means the oil companies are acting as a judge in their own cause, in violation of the rules of natural justice.

According to the official estimates of the Nigerian National Petroleum Corporation (NNPC), a total of appropriately $2300 \mathrm{~m} 3$ of oil is spilt in 300 separate incidents annually. "However, as the oil companies [including the NNPC] frequently underestimate the quantity of oil spilt and a large number of other spills go unreported, the total volume of oil spilt may be 10 times higher than the official figure." Moffat / Linden, supra n.120, at 532. See also Awobajo, An Analysis of oil spill incidents in Nigeria: 1976-1980 - Paper presented at the seminar on the Petroleum Industry and the Nigerian Environment, organised by the NNPC at the Petroleum Training Institute, Warri, 912 November 1981. 
surface water used for drinking, fishing and other household and industrial purposes. The percolation of industrial wastes (drilling and production fluids, buried solid wastes, as well as spills of crude) into the soil contaminates ground water aquifers." ${ }^{140}$ The impact of the Funiwa- ${ }^{141}$ oil blow-out on the affected areas illustrates this observation. Investigations at Fishtown (one of the impacted areas) eighteen months after the blow-out showed the top soil and ground water still contaminated. ${ }^{142}$ Yet all these are not counted in the assessment of damages due to the victims under the LUA.

Since oil is statutorily and exclusively vested in the state, oil-bearing communities of the Niger Delta are not entitled to rents and royalties paid for the exploitation of oil in their lands by the oil companies. Annual land rent was an important way by which the people partook in oil revenue.

The Niger Delta people are "minority groups" ${ }^{143}$ in the Nigerian federation and there is no constitutional or other legal provision guaranteeing them access to political power at the centre where they can take or partake in decisions on how oil revenue can be utilized. Annual land appeared to be their only consolation.

The Niger Delta remains undeveloped despite the enormous revenue derived by the Nigerian state from the exploitation of oil in their homestead. According to a recent World Bank report, "of the resources available in the Niger Delta, oil is by far the most valuable to the national economy. However, the benefits to the Niger Delta region is less obvious." "144 It seems the situation is worse today since they are no longer considered as stakeholders in any sense whatsoever.

The Niger Delta people are amongst the poorest people in Nigeria, despite the huge revenue derived from oil exploited from their lands. This poverty is accentuated by the despoliation of their lands by the activities of the oil companies. In the words of an observer: "Ironically, the oil industry which has brought development to many parts of Nigeria, has

141 The Funiwa-5 blow-out was a major oil spill in Nigeria in the early 1980s; the quantity of oil spilled was enormous and the damage it caused was extensive. Yet the oil companies concerned showed great insensitivity and inhumanity on the handling of the spill and on the issue of compensation. For a case-study of that incident, see Hutchful, Oil Companies and Environmental Pollution in Nigeria, at 124-135.

142

Oteri, Effect of oil spills on Groundwater, 1981 (cited in Hutchful, Oil Companies and Environmental Pollution in Nigeria, at p. 118.

143 See Osaghae, Ethnic Minorities and Federalism in Nigeria, (1991) 90, African Affairs, 237-258, esp. at pp. 248-258.

144

World Bank, Defining An Environmental Strategy For the Niger Delta, at p. 81. 
become a source of misery to the people of oil-producing communities whose existence is now threatened by the scourge of oil pollution.",145

There is an alliance between the Nigerian state (controlled by the majority ethnic groups) and the oil companies which helps to deprive the Niger Delta people of employment in the oil companies, with the result that unemployment abound in the Niger Delta. Annual rents compensation had been a source of some income for the people.

Since the enactment of the LUA, the oil companies no longer approach the communities to negotiate access to land for oil operations, on terms of payment of compensation, as was the case before. ${ }^{146}$ In fact, "it is possible for the government to acquire a vast area of land for petroleum purposes, i.e. granting the operator a lease over a large area, yet the villages will know nothing about the acquisition" ${ }^{, 147}$; they wake up one morning to find that the government has given out their farmland to oil operators. ${ }^{148}$ Hence the feeling of participation in the exploitation of oil found in their land has been lost and this has accentuated a sense of deprivation.

Protests over the injustice of the LUA by the Niger Delta people had been met with gross violation of human rights by the government. Several lives have been lost in clashes between protesters and government security agencies. ${ }^{149}$

In enacting the Land Use Act, the federal government showed bias against the Niger Delta people by ignoring a positive recommendation of the Land Use Panel which it had set up to make recommendations for land reform. The panel had recommended that the "federal government should take a serious look at the effects of oil exploration and exploitation" with a view to "improving the quantum of compensation payable to land owners" and to compelling oil companies into "complete reclamation" of all leased land. ${ }^{150}$ This recommendation was borne out of their findings in the Niger Delta. Adewale, supra n. 107, at p. 95 (footnote 31).

Often some portion of the land is fenced and barred to 'trespassers'.

149 See Human Rights Watch, The Price of Oil - Corporate Responsibility and Human Rights Violations in Nigeria’s Oil-Producing Communities, Human Rights Watch, New York, 1999. 
Because they no longer pay compensation for any damage to the land itself, the oil companies have tended to be more reckless in their operations in the Niger Delta. ${ }^{151}$

As we shall see presently, the Niger Delta people see the impact of the LUA on them as bordering on expropriation ${ }^{152}$ and injustice. ${ }^{153}$ It would appear that they are not rid of the conviction that oil belongs to them, being traditionally part of their land. Hence they are struggling for justice: to regain possession of their 'seized' property; to end the despoliation of their environment by reckless oil operations. Two instances will illustrate this point. Firstly, in 1993 the Ogoni ethnic group of the Niger Delta boycotted a presidential election on the argument that "Ogoni should not give legitimacy to a president who would swear to uphold a constitution [the LUA has been part of the Nigerian constitution since 1979] that dispossessed Ogoni people of their natural rights." several international bodies. ${ }^{155}$ The second instance relates to a recent action by some dissatisfied youths of the Niger Delta. On 11 December 1998, Ijaw youths organisations gathered under the umbrella of Ijaw Youths Congress (IYC) at a place called Kaiama and issued a Declaration which they called 'Kaiama Declaration' ${ }^{156}$. Part of this Declaration reads: ${ }^{157}$

"All lands and natural resources (including mineral resources) within the Ijaw territory belong to the Ijaw communities and are the basis of our survival...We cease to recognise all undemocratic Decrees that rob our peoples/communities of the right to ownership and control of our lives and resources, which were enacted without our participation and consent. These include the Land Use Decree and the Petroleum Decree, etc..."

These two instances appear to aptly illustrate the observation of a learned author in a similar context:

The annual Reports of the Civil Liberties Organisation and those of other non-governmental organisations are replete with reports of the devastation of operational lands.

For arguments whether or not the Land Use Act expropriates, see: Omotola, Special Comments Does the Land Use Act Expropriate?, (1985) 3, Journal of Private and Property Law, 1; Umezurike, Does the Land Use Act Expropriate? Another View, (1986) 5, Journal of Private and Property Law, 61.

'Injustice' is the antithesis of 'justice'. In a recent case, the Nigerian Supreme Court pointed out that "the test for justice is what a fair minded ordinary person would say as to whether justice has or has not been done. The essence of justice is fairness - fairness to everyone." See Engineering Enterprise v. A.-G. [1987] 2 N.W.L.R. (part 57) 381, at 385.

154 Quoted in Naanen, supra n. 21, at p. 70.

155 Like the UN and the UNPO.

156 For the full text, see: http://www.nigerianext.com/Ijawdeclare.html

157 See Human Rights Watch, The Price of Oil, supra n. 149, at 130. 
"There are, indeed, many different methods of expropriation, but, so far as the dispossessed owner is concerned, they... do not necessarily rid [him] of his conviction that he is the owner, and that he should be entitled, if not to secure his reinstatement as an owner, then at least to claim some compensation for his disappointment."

\section{Concluding remarks}

It has become a platitude to point out that the Nigerian state, like most other African states, was an artificial creation. Yet the recent Kaiama Declaration restated the point when it said: "it was through British colonisation that the Ijaw nation was forcibly put under the Nigerian state." This is an unequivocal attack on the legitimacy of the Nigerian state, and (located in the context of the entire Declaration) an indication that the issue of state legitimacy and ownership of natural resources are still current political issues in Nigeria. In fact, in a recent statement the Rivers state Study Group poignantly said:

"At the moment the colonial government left Nigeria... there was no doubt in the minds of the Oil Rivers Peoples [as the Niger Delta people were generally known during the colonial era] that natural resources and in particular land, petroleum resources and other economic potentialities belonged to the autochthonous peoples of 'Nigeria' wherever they were and we had no misgivings of the magnitude that a Petroleum Decree and a Land Use Decree would emerge, whereby all the most important natural resources of our peoples would be confiscated by the central government...,159

This article has amply demonstrated the hardship and injustice which the LUA is occasioning to the Niger Delta minorities. While other aspects of injustice (such as environmental degradation and under-development of the region) may take some time to redress, this is not the case with the injustice brought about by the provisions of the LUA. This can be quickly ended by the repeal of the LUA; what is required is the political will to do it. Sustained protests and demands for equity, despite repressive actions by the government, indicate that the struggle is the life of the people. It does not seem that token responses like the recent establishment of the Niger Delta Development Commission ${ }^{160}$ can be an answer to the injustice of the LUA. The people are demanding the repeal of the

Wortley, Expropriation in Public International Law, Cambridge University Press, Cambridge, 1959, p. 4.

Established by a Federal law in 2000; the Commission was constituted in early 2001. The Delta state governor recently alleged that the commission is not doing anything because it is being starved of funds by the federal government. See "Ibori Accuses FG of Starving NDDC of Funds". Post Express, 4 April 2001. 
LUA. ${ }^{161}$ More than that, they are demanding the right to control their natural resources. ${ }^{162}$ "Claims long dormant are being asserted in ways that call for answers, not merely token responses or outright repression." "163 The recalcitrance of the government to address the issues raised in a concrete way poses a great danger to the Nigerian state. ${ }^{164}$ As a recent report surmises, "the lingering crisis in the Niger Delta constitutes a threat to peace and stability, and therefore to democratic consolidation in the larger Nigerian society." "The repeal of the LUA may force a truce, as it would end the injustice it is presently visiting on the people. Hence, the position of this article is that the LUA should be repealed ${ }^{166}$ without further delay.

161 See Kaiama Declaration, 1998.

162 Ibid.

163 Sigler, Minority Rights: A Comparative Analysis, Greenwood, London: 1983, p. 176.

164 Citing the example of the Nigerian civil war, Sigler has observed: "Many nations have failed to 165 give due attention to minority rights and paid a price in blood.” Sigler, Minority Rights, at p. 196. International IDEA, Democracy in Nigeria: Continuing Dialogue(s) for Nation-Building, supra $\mathrm{n}$. 9, at p. 149.

166 The objectionable issues in the LUA are legion, and these cannot be properly cured by amendments. A comprehensive amendment of all the objectionable provisions will take as much time as the making of a new law, and what will emerge will certainly not be an amendment of the LUA; it will be a new law. So it will be better and neater to repeal the Act in its entirety and start anew if it is really desired to reform the pre-existing customary land tenure system. The advantage of repeal also lies in its ability to quickly end its present injustice to the Niger Delta people and thereby reduce the tension it is presently generating in the country. 